Синтез поликристаллических образцов осуществлялся методом твердофазных реакций по одноступенчатой технологии. Структурные исследования проводилась с помощью рентгеновского дифрактометра Bruker D8 Advance в CuKa излучении. Электросопротивление измерялось стандартным четырёхзондовым методом на поликристаллических компактированных образцах в интервале температур 5-300 K.

Установлено, что замещение по анионной подрешетке является неограниченным: получен ряд твердых растворов замещения. Все соединения кристаллизуются в гексагональной сингонии. При концентрации $\mathrm{x} \leq 0.5$ сохраняется пространственная группа $P 6_{3} 22$, свойственная для кирального соединения $\mathrm{Cr}_{0.33} \mathrm{NbS}_{2}$. Атомы хрома занимают две частные позиции $\mathrm{Cr}(2 \mathrm{~b})\left(\begin{array}{lll}0 & 0 & 1 / 4\end{array}\right)$ и $\mathrm{Cr}(2 \mathrm{c})(1 / 32 / 3$ $1 / 4)$, атомы ниобия занимают одну частную позицию $\mathrm{Nb}(2 \mathrm{a})\left(\begin{array}{l}0 \\ 0\end{array}\right)$ и общую $\mathrm{Nb}$ (4f) $(1 / 32 /$ z), а атомы халькогенов находятся в позиции X(12i) (х у z). При более высоких концентрациях селена возможен переход к пространственной группе $P 6_{3} / m c m$. При этом атомы хрома упорядочены в цепочки $\sqrt{3} a_{0} \times \sqrt{3} a_{0}$, где $a_{0}-$ параметр решетки $\mathrm{NbX}_{2}$. Все соединения обладают металлическим типом проводимости с аномалией в области магнитного перехода.

1. Togawa, Koyama T., Takayanagi K. et. al., Phys. Rev. Lett., 108, 107202 (2012)

2. Gubkin A.F. et al., J. of App. Phys., 119, 013903 (2016)

\title{
EFFECT OF FORCED CONVECTION ON DENDRITE GROWTH KINETICS
}

\author{
Toropova L.V. \\ Ural Federal University, Yekaterinburg, Russia \\ E-mail: 1.v.toropova@urfu.ru
}

Annotation. In this work, using currently developing model of convective transport and dendrite growth, results on theoretical modeling are presented. A stable relation for the dendrite tip velocity $V$ and its tip diameter $\rho$ via the selection theory and undercooling balance is discussed. It is shown that convective transport plays essential role in quantitative description of dendrite growth kinetics.

The generalized selection criterion determines a combination between $V$ and $\rho$ in the case of anisotropic thermo-solutal dendritic growth with allowance for the convective heat and mass transport mechanism in the case of n-fold crystalline symmetry 


$$
\sigma^{*}\left(\rho, P_{g}\right)=\frac{\sigma_{0} \alpha_{d}^{\frac{5}{n}} A_{n}^{\frac{5}{n}}\left(1+b D_{T} \beta_{1}\right)\left(1+\mu \tau_{1}^{\frac{n+5}{2(n-1)}}\right)^{2}}{\left[1+v_{1}\left(\alpha_{d}^{\frac{3}{n}} A_{n}^{\frac{3}{n}} \rho b+\frac{3 \alpha_{d}^{\frac{1}{4}} A_{n}^{\frac{2}{n}} P_{g} \beta_{1} D_{T}}{2^{\frac{1}{4}} d_{0}}\right)\right]^{2}}+\frac{2 \sigma_{0} \alpha_{d}^{\frac{2}{n}} A_{n}^{\frac{2}{n}} D_{T} \beta_{1}}{\rho},
$$

The second relation connecting $V$ and $\rho$ with the driving force of crystallization is the undercooling balance condition [1]. The total undercooling $\Delta T=T_{0}-T_{\infty}$ includes the following contributions at the tip of growing dendrite

$$
\Delta T=\Delta T_{T}+\Delta T_{C}+\Delta T_{R}+\Delta T_{K},
$$

where $T_{\infty}$ is the temperature far from the dendritic tip, $\Delta T_{T}$ and $\Delta T_{C}$ represent the thermal and solutal undercoolings, respectively, $\Delta T_{R}=2 d_{0} T_{Q} / R$ is the undercooling contribution arising due to the Gibbs-Thomson effect, and $\Delta T_{K}=V / \mu_{k}$ stands for the kinetic contribution ( $\mu_{k}$ is the kinetic coefficient).

Expressions

$$
\Delta T_{T}=T_{i}-T_{\infty}=\frac{T_{Q} V k_{s}}{\alpha_{h} \rho_{l} c_{l} u_{*} D_{T}}, \Delta T_{C}=m\left(C_{i}-C_{l \infty}\right)=\frac{\left(1-k_{0}\right) V m C_{l \infty}}{a_{m} u_{*}-\left(1-k_{0}\right) V}
$$

demonstrate that $\Delta T_{T}$ and $\Delta T_{C}$ are independent of $\rho$. The undercooling balance condition (2) represents a relation connecting the interfacial temperature $T_{i}$ at the dendritic tip and the far-field temperature $T_{\infty}$ in the undercooled liquid phase.

Keeping in mind that the total undercooling $\Delta T=T_{0}-T_{\infty}$ is constant and combining expressions (2) and (3) one can write out the explicit function $\rho(V)$ in the form

$$
\rho(V)=\frac{4 d_{0} T_{Q}}{\Delta T-\Delta T_{T}(V)-\Delta T_{C}(V)-V / \mu_{k}}
$$

Now substituting $\rho(V)$ from (4) into (1), we come to the implicit equation for the dendritic velocity $V$ of the form

$$
\frac{\rho^{2}(V) V}{2 d_{0} D_{T}} \sigma^{*}(\rho(V), V)=1,
$$

where $\sigma^{*}(\rho(V), V)$ is determined by the right-hand side of equation (1) after substitution of $\rho(V)$ from expression (4). Thus, relations (4) and (5) represent the exact analytical solution if the convective heat and mass transport completely defines the stable dendritic growth.

Figure 1 shows the comparison of the model predictions for the boundary conditions of the conductive and convective types as well as the experimental data on dendrite velocities obtained for solidifying $\mathrm{Ti}_{45} \mathrm{Al}_{55}$. 
ФТИ-2019

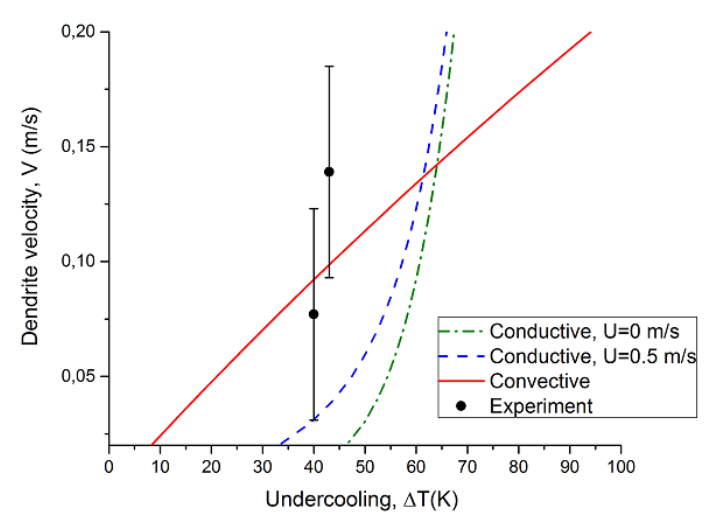

Fig. 1. Comparison of model predictions with experimental data on the dendrite growth kinetics in $\mathrm{Ti}_{45} \mathrm{Al}_{55}$.

Predictions with conductive boundary conditions in stagnant melt $(U=0 \mathrm{~m} / \mathrm{s})$ and under forced flow $(\mathrm{U}=0.5 \mathrm{~m} / \mathrm{s})$ are taken from [2]. Predictions with convective boundary conditions are given using the present model. Experimental points are taken from Hartmann et al. [3] for the smallest flow velocity at which the low-velocity limit of dendritic growth is developed in the present model with convective boundary conditions. Error bars indicate uncertainty in experimental measurements of the crystal growth velocity by high-speed camera in droplets processed in an electromagnetic levitation facility.

Toropova L. V. acknowledges the support from the Ministry of Education and Science of the Russian Federation [grant number 1.12804.2018/12.2].

1. Alexandrov D.V., Galenko P.K., Toropova L.V., Phil. Trans. A, 376, 20170215 (2018).

2. Galenko P.K., Danilov D.A., Reuther K., Alexandrov D.V., Rettenmayr M., Herlach D.M., J. Cryst. Growth, 457, 349-355 (2017).

3. Hartmann H., Galenko P.K., Holland-Moritz D., Kolbe M., Herlach D.M., Shuleshova O., J. Appl. Phys., 103, 073509 (2008).

\title{
$5 d \rightarrow 4 f$ LUMINESCENCE IN SrgLu(PO 4$)_{7}$ DOPED WITH Pr $^{3+}$ IONS
}

\author{
Trofimova E.S. ${ }^{*}$, Pustovarov V.A. ${ }^{1}$ Shi Q. ${ }^{2}$ \\ 1) Ural Federal University, Yekaterinburg, Russia \\ 2) Taiyuan University of Technology, 030024, Taiyuan, China \\ *E-mail: trofimova.e.s@yandex.ru
}

The evolution of medical imaging techniques (computed tomography, positron emission tomography) has triggered the search for new fast scintillator materials for photon radiation detectors because it can improve the image resolution. Although most of the currently used scintillators are using fast $5 d \rightarrow 4 f$ transitions in $\mathrm{Ce}^{3+}, \mathrm{Pr}^{3+}$ has even faster $5 d \rightarrow 4 f$ emission and is widely studied as a prospective scintillator material [1]. 